\title{
異なる光環境に生育する室内緑化樹木の光合成特性
}

\section{Photosynthetic Characteristics of Interior Trees under Different Light Environment}

\author{
中村彰宏 ${ }^{*}$ 奥村信一** 中川育男 ${ }^{* * *}$ 森本幸裕 ${ }^{*}$ \\ Akihiro NAKAMURA Shinichi OKUMURA Ikuo NAKAGAWA Yukihiro MORIMOTO
}

摘要：異なる光環境（全天光下, 遮光下, 室内）に生育するモッコク, クロガネモチ, モチノキ, カ ラタネオガタマの常緑広葉樹 4 種の光合成特性を，切り枝を用いてアトリウム空間で測定した。これ ら 4 種の樹木は, 暗呼吸速度, 光補償点が, 同時に測定を行った陽樹のアカメガシワに比べて小さく, 異なる光合成特性を示した。およそ70\%の遮光条件下では, 野外の全天条件下に比べ多少耐陰性が 增加し, 室内条件下ではさらに耐陰性が増加した。屋外または遮光条件下のモチノキ, クロガネモチ は, 高光量域でアカメガシワと同程度の大きな光合成速度を示すが, 室内条件下では, 熱帯林林床の 樹木に近い小さな暗呼吸速度，光補償点を示し，光合成の可塑性が大きな樹種と考えられた。

\section{1.はじめに}

近年アトリウム空間を含めた室内での緑化事例か増加している。 しかし室内空間での緑化に関する研究は, 海外でFicus benjamina をはじめとした熱帯地方原産の観葉植物を対象とし た研究3446)などは盛んに行われているものの, わが国における研 究事例は多くなく, また日本原産の樹木を対象とした研究事例 ${ }^{10)}$ が十分あるとは言えない。アトリウムなどの室内空間に植物を植 栽する場合には, 急激な環境条件の変化から生じるストレスによ る成長量の低下, 枯死等を防止するために順化処理が必要とされ $ろ^{11115)}$ 。低光量条件下のアトリウム空間への導入時には, 様々な 環境変化の中でも, 光環境の变化が大きいため, 光順化を十分に 行う必要がある。

従来, 異なる光環境下および光環境変化が与える植物の光合成 特性に関する研究は, 森林遷移解明の目的での熱帯林を構成する 種特性 ${ }^{8118)}$, 陽性および陰性植物の特性 ${ }^{2)}$, 果樹における異なる 遮光率が生育, 生理特性に与える影響 ${ }^{12)}$, また観葉植物の室内緑 化を想定しての順化特性 ${ }^{6)}$ などがある。わが国においても, 日本 に自生する樹種を対象として, 森林の遷移機構解明を目的とした 樹種特性 ${ }^{5)}$, 林業における施業に伴う光環境変化が生理特性に与 える影響評価 ${ }^{13211}$, 光環境の異なる樹冠部位や異なる葉齢での光 合成特性の相違に関する研究 ${ }^{7}$ などはあるあのの, 室内緑化を目 的とした光順化や光環境变化が光合成特性に与える影響に関する

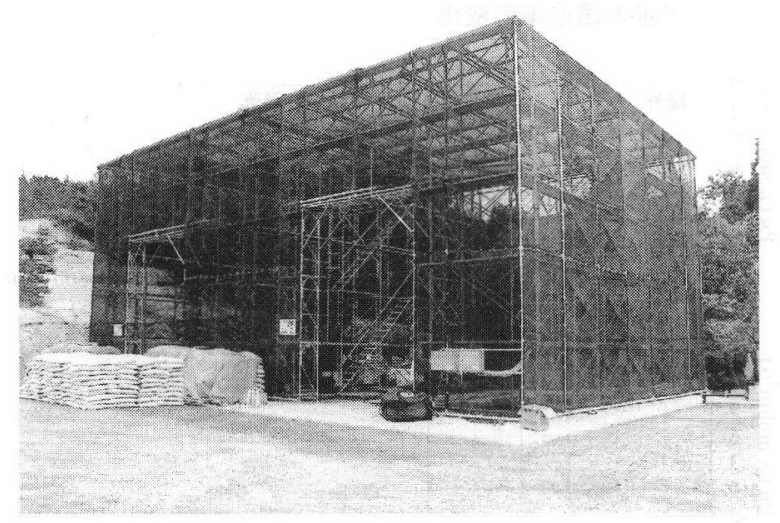

写真 -1 遮光条件下の順化施設
研究はない。

そこで低照度条件下で生育が可能な，わが国原産の植栽樹木な ぞ 4 種の常緑広葉樹を対象に, 光順化に伴う光合成特性変化の解 明を目的として, 光環境の異なる屋外, 遮光, 室内の 3 条件下に 生育する個葉の光合成速度の測定を行い, 光合成特性から光順化 および而陰性について考察を行った。

\section{2. 調查地および調查方法}

\section{（1）実験場所とその光環境調查}

光環境の異なる屋外, 遮光, 室内に生育する 3 条件下の植栽樹 木の切り枝を用いて光合成速度の測定を行った。屋外条件下とし ては, 大阪府堺市に位置する大阪府立大学構内の全天光下に生育 する樹木を, 遮光条件下としては, 大阪府泉佐野市に設置された 順化施設内に生育する樹木を, 室内条件下としては, 大阪府泉佐 野市および泉南市に位置する関西国際空港のアトリウム空間に生 育する樹木を測定に用いた。

順化施設は，鉄パイプで組まれた高さ $8.5 \mathrm{~m}$ ，長さ $18.5 \mathrm{~m}$ ，幅 $13 \mathrm{~m}$ の大きさである。骨組み周辺部には遮光率がおよそ $70 \%$ の ネットがかけられており，この中に順化中の樹木が設置されてい

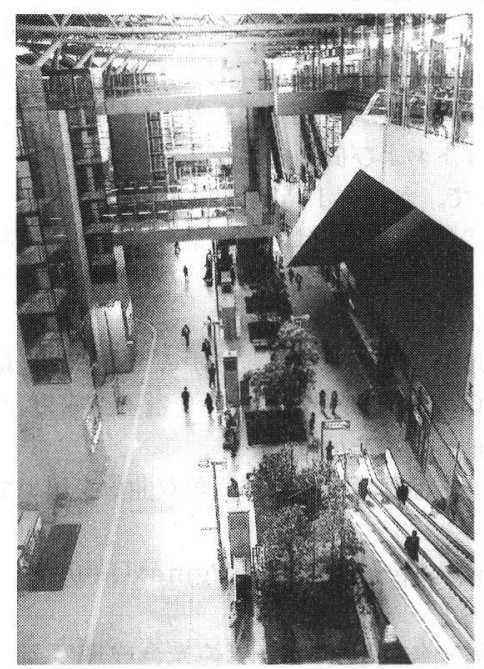

写真－２＼cjkstart関西国際空港のアトリウム

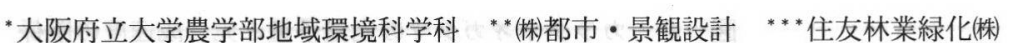


る(写真 1 )。

関西国際空港のアトリウムは（写真 2 )，1994 年に開港した旅 客ターミナルビル内のキャニオンと呼ばれる空間である。このア トリウム空間は, 高さおよそ $27 \mathrm{~m}$, 長さ $275 \mathrm{~m}$, 奥行き $27 \mathrm{~m}$ の 大きさである。天井部にはトップライトが設けられ，太陽光が入 射している。このキャニオンの 1 階部分に, およそ $4 \mathrm{~m}$ 四方の大 きさの植栽枡が 34 個設けられ, 各植栽枡に樹高 $4-7 \mathrm{~m}$ の, 主と して日本原産の常緑広葉樹が 2-3 本植えられている。

\section{(2) 植物材料}

光合成速度の測定に用いた樹木は, 日本原産の耐陰性を有する と考えられている ${ }^{16}$ モッコク (Ternstroemia gymnanthera), クロガネモチ (Ilex rotunda), モチノキ (Ilex integra) およ び中国原産のカラタネオガタマ(Michelia figo) の 4 種である。 またこれらの耐陰性を有する ${ }^{16)}$ と考えられる常緑広葉樹との比較 のために, 大阪府立大学構内に生育する, 陽樹 ${ }^{17199}$ のアカメガシ ワ (Mallotus japonicus) の光合成速度測定も同時に行った。

測定に用いた各条件下に生育する樹木の樹高は, いずれも $3-$ $6 \mathrm{~m}$ であった。遮光条件下の樹木は, 1997 年 4 月下旬に, 根系 部が完全に根洗いされた後，多孔質焼成培土をむつステンレス製 のコンテナにて啋耕栽培がなされている。潅水は, ドリップチュー ブによる自動潅水および施設上部より葉面への定期的なミスト潅 水が行われている。

室内条件下の樹木は, 1994 年 6, 7 月におよそ 6 ヶ間, 上 記の 70\%遮光条件での順化を経て移植された。屋外条件下の測 定には，1997年に展開した当年葉を用い，遮光条件下では，順 化施設に移植された後に展開した葉を用いた。室内条件下では, 1997 年または前年の 1996 年に展開した比較的光量を受ける樹冠 外部に位置する葉を用いた。ただし大学構内および周辺に, 屋外 の全天光下に生育する樹高 $3-6 \mathrm{~m}$ の適当なモチノキが存在しな かったため,この条件下のモチノキの測定は行わなかった。ただ し参考として, 遮光条件下に生育する樹葉の中で, 順化施設に移 植する前年である 1996 年に展開した葉の光合成速度測定をあわ せて行った。

異なる光環境に生育する樹木の低光量域での光合成特性の比較 を行うため, 生育地での測定ではなく, 温湿度環境がほぼ一定な, アトリゥム環境下で, 切り枝を用いて, 光合成速度の测定を行っ た ${ }^{13211}$ 。測定に用いた葉は, 前日または当日朝に, 枝の水切り処 理を行い, 三角フラスコ内に設置し, 光合成速度を測定した。

\section{（3）光環境と光合成速度の測定方法}

光合成速度の測定は, 空調のなされている関西国際空港のアト リウム空間の 1 階部で，1997 年 7 月から 9 月にかけて携帯式光 合成・蒸散速度测定装置（LI-COR 社；LI-6200）で行った。测 定はトップライトおよび側面のガラスからの入射光のもとで, 8 時から 20 時まで, およそ 1 時間毎に測定を行った。なお光量が ゼロである時の暗呼吸速度は, 測定葉を 1 時間程度暗黑条件下に 設置したのちに，チャンバーを黑色の布およびポリエチレン袋で 覆い測定した。

また各生育地の光環境を明らかにするために, 光量子計（英弘 精機; ML-020P) による光合成有効光量子束密度（以下光量子 量とする）の連続測定を行った。

なお光一光合成曲線は次式の非直角双曲線を用いて回帰を行っ た。 ${ }^{20)}$

$m P g^{2}-(a Q+P g \max ) P g+a P g \max Q=0$

$\mathrm{Pn}=\mathrm{Pg}-\mathrm{Rd}$

ここで Pg は総光合成速度, $\mathrm{Pn}$ は純光合成速度, $\mathrm{Rd}$ は暗呼吸 速度, Pgmax は飽和光合成速度, $\mathrm{Q}$ は光量子量, $\mathrm{m}$ は曲線の 曲率，aは初期勾配である。

\section{3. 結果および考察}

（1）各条件の光環境

まず快晴日の 1997 年 8 月 28 日および罢天日の 9 月 25 日の各 生育地の光量子量および透過率の日変化を図 1 に示した。快晴日 は屋外の光量子量が日中 $2000 \mu \mathrm{mol} / \mathrm{m}^{2} / \mathrm{s}$ 程度に上昇するが, 曇天日は $1000 \mu \mathrm{mol} / \mathrm{m}^{2} / \mathrm{s}$ 程度であった。一方, 遮光条件下の 光量子量は, 快晴日は日中の最大值が $550 \mu \mathrm{mol} / \mathrm{m}^{2} / \mathrm{s}$ 程度で, 透過率は 20-30\%程度であった。直達日射が施設内の構造物の 陰となることがあり，時折光量子量および透過率が大きく減少す ることがあった。一方, 雲天日の光量子量の最大值は $200 \mu \mathrm{mol}$ $/ \mathrm{m}^{2} / \mathrm{s}$ 程度, 透過率は 10-20\%と晴天日に比べ小さかったこ。 の毁天日の透過率の低下は, 散乱日射量が日射量に占める割合が 大きくなったため生じたと考えられる。アトリウム空間の晴天日 の光量子量は, 従来の報告のように ${ }^{(4)}$ ，正午付近の数時間のみ相 対的に大きな $220 \mu \mathrm{mol} / \mathrm{m}^{2} / \mathrm{s}$ 程度の光量子量, $12 \%$ の透過率 であったが，10 時以前および 14 時以降はおおむね $2 \%$ 程度の極 めて小さな透過率であった。昙天日は, 直達日射による透過光が 極めて小さいため, 日中を通じて $4 \%$ と小さな透過率であった。 (2) 光量子量亡光合成速度の関係

図 2 に 8 月 12 日のカラタネオガタマの光量子量と光合成速度 の関係を示した。この測定日のアトリウム空間内の気温および葉 温は $28^{\circ} \mathrm{C}$ 程度, 湿度は $60 \%$ 程度, 二酸化炭素濃度は, 旅客夕一 ミナルという人の多い閉鎖空間であるため $590 \mathrm{ppm}$ 程度と屋外 での通常の值に比べ $200 \mathrm{ppm}$ 程度高い状態であった。従来より,

一酸化炭素濃度上昇による光合成速度の増加が報告されており ${ }^{97}$, 図 2 に示された光合成速度は, 通常屋外の同一光量条件下で観測 される光合成速度に比べ多少大きな值である可能性がある。いず
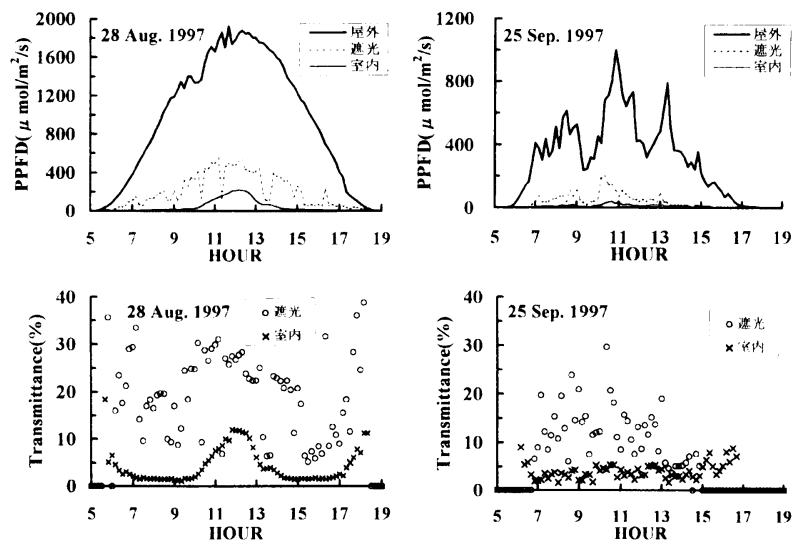

図-1 屋外, 遮光, 室内条件下での晴天日および䍗天日の光量 子量と透過率の变化
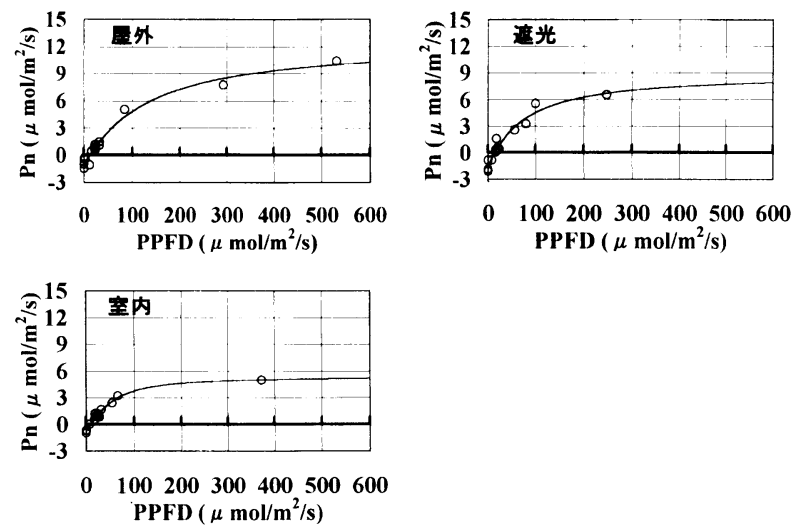

図－２カラタネオガタマの光量子量と光合成速度の関係 
れの 3 条件下の測定葉ともに, 光量子量の増加に伴い, 光合成速 度が增加しており, 光量子量と光合成速度の高い相関が見られ, 光合成速度が光量子量に大きく規定されていることがわかる。光 合成速度の測定は，トップライト部および側面のガラス部からの 透過光を利用して行ったため, 図 1 に示されるように, 高光量域 でのデータが少ない。それゆえ 1，2 式による光一光合成曲線の 回㷌では, 飽和光合成速度や高光量域での光合成速度の推定值の 信頼性に欠ける。しかし，本研究では低光量条件下である室内空 間での生育特性の評価を目的に行っているため, 低光量域のデー 夕のみを注目しここれらのデータを用いて解析を進めた。1，2 式の回㷌による結果は図 2 中の回帰曲線からもわかるように，い ずれの測定日の相関係数がほぼ 0.9 を越え，1，2 式による光一 光合成速度の関係が良好に回帰できた。

図 3 に, 異なる光環境である屋外, 遮光, 室内の 3 条件下に生 育させた常緑広葉樹 4 種の光一光合成曲線を示した。低光量条件 下での光合成特性を考察するため, $100 \mu \mathrm{mol} / \mathrm{m}^{2} / \mathrm{s}$ までの光 量子量域の特性を示した。いずれの樹木も, 室内条件下の暗呼吸 速度が他の条件下での值よりも小さい。光補償点に関しても，全 ての樹木で室内条件下の值が最も小さかった。またアトリウム空 間では相刘的に大きな $100 \mu \mathrm{mol} / \mathrm{m}^{2} / \mathrm{s}$ の光量時の光合成速度 は，屋外条件下に比べ室内，遮光条件下では小さな值であった。 しかしクロガネモチは，室内環境下でも植栽樹木の中で相対的に 大きな光合成速度が測定されており ${ }^{13}$, 光量子量が $100 \mu \mathrm{mol} /$ $\mathrm{m}^{2} / \mathrm{s}$ では, 3 条件下の中で最む大きな光合成速度であった。

\section{（3）アカメガシワとモチノキ, クロガネモチの光合成特性}

陽樹のアカメガシワと, 屋外条件下に生育するクロガネモチ, そして前年に葉を展開させ，その後遮光条件に移植されたモチ，
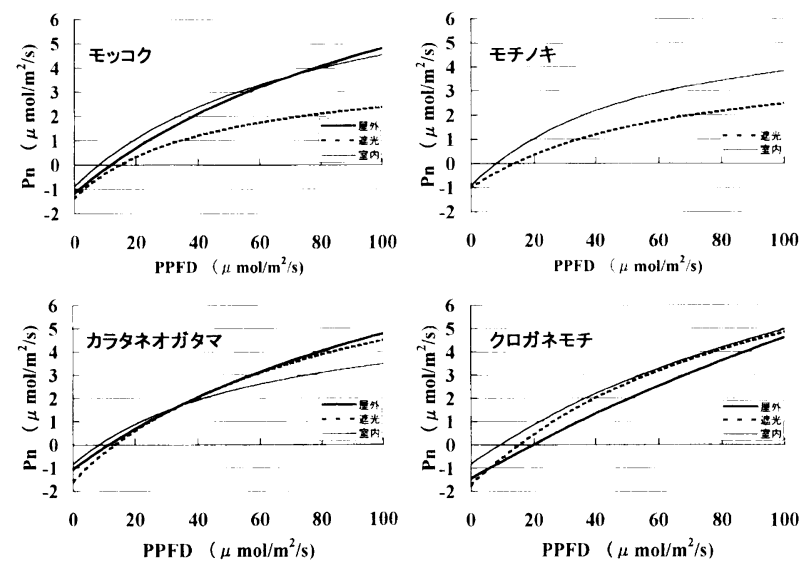

図-3 低光量域での光一光合成曲線
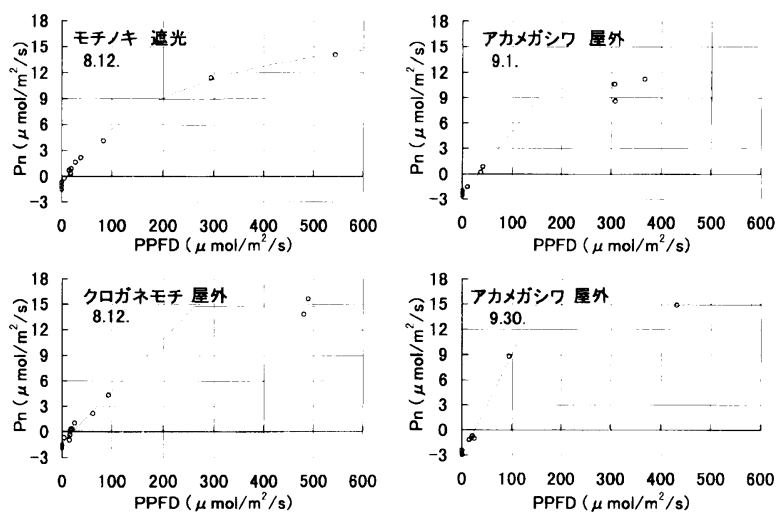

図-4 屋外および遮光条件下に生育する樹木の光一光合成曲線
キ旧葉の光量子量と光合成速度の関係を図 4 に示した。すでに筆 者らはモチノキ, クロガネモチは, 室内環境下における 11 種の 室内緑化樹木の中で, $500 \mu \mathrm{mol} / \mathrm{m}^{2} / \mathrm{s}$ と室内環境としては大 きな光量時に, 相対的に大きな光合成速度を示したとの報告して いる ${ }^{14)}$ 。屋外に生育するモチノキ, クロガネモチむ, 水分ストレ スの生じていないと考えられる切り枝では, $500 \mu \mathrm{mol} / \mathrm{m}^{2} / \mathrm{s}$ の光量子量の時に，およそ $15 \mu \mathrm{mol} / \mathrm{m}^{2} / \mathrm{s}$ の大きな光合成速度 であった。同様の傾向はアカメガシワでも見られ，耐除性を有す ると考えられるモチノキ, クロガネモチと, 陽樹のアカメガシワ の高光量域における光合成特性に，ほとんど差は見られなかった。 従来陰性および陽性植物の飽和光合成速度は, 大きく異なると言 われており ${ }^{2)}$ ，この結果を適用するとモチノキ，クロガネモ千も アカメガシワと同様に陽樹と考えられる。ただし，9月30日に 測定したアカメガシワは, $100 \mu \mathrm{mol} / \mathrm{m}^{2} / \mathrm{s}$ 程度の低光量子量 条件下で $9 \mu \mathrm{mol} / \mathrm{m}^{2} / \mathrm{s}$ もの光合成速度を示し, 比較的光合成 速度の大きなモチノキ, クロガネモチの 2 倍程度の值であった。 この傾向は, 同時に測定された気孔コンダクタンスが, モチノキ, クロガネモチにおける $100 \mu \mathrm{mol} / \mathrm{m}^{2} / \mathrm{s}$ の光量子量の時に, 0.1 $\sim 0.2 \mathrm{~mol} / \mathrm{m}^{2} / \mathrm{s}$ であるのに対し，アカメガシワは 3 倍程度の 約 $0.6 \mathrm{~mol} / \mathrm{m}^{2} / \mathrm{s}$ を示していたことからも裏付けられる。陽樹 であるアカメガシワは, 水分条件が良好であれば, 低光量条件下 でも, 極めて大きな光合成速度を示し, 高光量域で大きな光合成 速度を示すモチノキやクロガネモチとは特性の異なることが明ら かとなった。

\section{（4）暗呼吸速度および光補償点の相違}

帐 5 に 7 月から 9 月までの各測定日に得られた式 1，2 の回州 式から算出した暗呼吸速度および光補償点の平均值を示した。な おアカメガシワは 2 個体のデータを示した。暗呼吸速度は, 陽樹 のアカメガシワでは $2.5 \mu \mathrm{mol} / \mathrm{m}^{2} / \mathrm{s}$ 以上之, すべての樹木の 中で最高值を示した。また光補償点も, 屋外条件下の樹木と大き な相違はないが， $30 \mu \mathrm{mol} / \mathrm{m}^{2} / \mathrm{s}$ 程度と最も大きな值を示し， 典型的な陽性植物の特徴を示した。

一方, 常緑広葉樹 4 種は, 暗呼吸速度がすべての樹木で $1.6 \mu$ $\mathrm{mol} / \mathrm{m}^{2} / \mathrm{s}$ 以下, 光補償点が 26 以下 $\mu \mathrm{mol} / \mathrm{m}^{2} / \mathrm{s}$, 陽樹之 異なる特性を示した。モチノキ以外のモッコク，カラタネオガ夕 マ, クロガネモチの暗呼吸速度は, 屋外および遮光条件下で 1.1 $\sim 1.5 \mu \mathrm{mol} / \mathrm{m}^{2} / \mathrm{s}$ であり, 両者に大きな变化が見られなかっ たが, モッコク, クロガネモチでは遮光による低下がわずかに見 られた。一方, 光補償点は, 屋外条件下で $24 \sim 26 \mu \mathrm{mol} / \mathrm{m}^{2} / \mathrm{s}$ であるのに対し, 遮光条件下では 15 23 $\mu \mathrm{mol} / \mathrm{m}^{2} / \mathrm{s}$ と低下し た。24\%, 47\%での遮光条件下のスターフルーッの暗呼吸速度, 光補償点は, 全天光条件下に比べ遮光率の增加とともに低下した との結果がある ${ }^{12)}$ 。本研究での, 遮光処理による暗呼吸速度の大
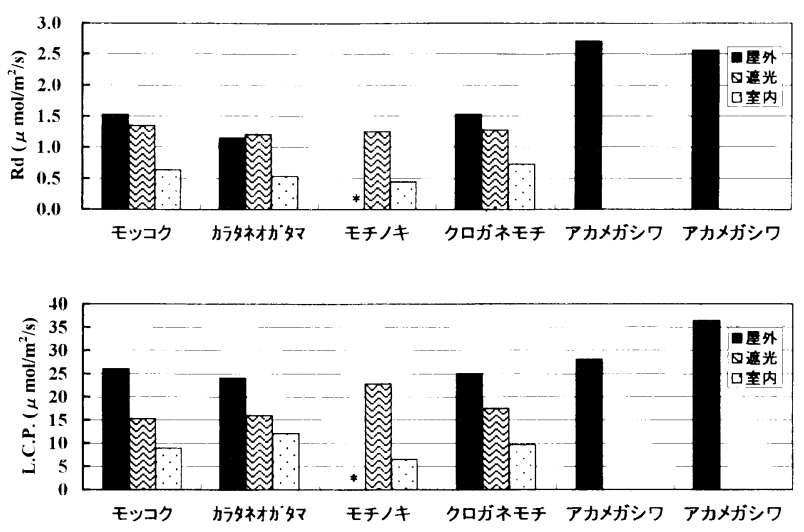

図-5 各樹種, 各条件下の暗呼吸速度 (上段) と光補償点 (下段) *モチノキの屋外条件下は測定せず 
きな低下は見られなかったが，光補償点が低下し，遮光処理によっ て耐陰性が多少増加したと考えられる結果は, 既存の報告と矛盾 するものではない。

また, 室内条件下では, 暗呼吸速度は $0.4 \sim 0.7 \mu \mathrm{mol} / \mathrm{m}^{2} / \mathrm{s}$, 光補償点は 6 $12 \mu \mathrm{mol} / \mathrm{m}^{2} / \mathrm{s}$ 之, 屋外, 遮光条件下に比べて 小さな値であり，耐除性が大きく増加したと考えられる。暗呼吸 速度および光補償点は, 八ワイの森林下層に生育する樹木で 0.12 $\sim 0.26 \mu \mathrm{mol} / \mathrm{m}^{2} / \mathrm{s}$ および $1.7 \sim 6.3 \mu \mathrm{mol} / \mathrm{m}^{2} / \mathrm{s}^{18)}$, 耐陰性を 有する熱帯の樹木の実生でおよそ $0.1 \sim 0.5 \mu \mathrm{mol} / \mathrm{m}^{2} / \mathrm{s}$ および $2 \sim 12 \mu \mathrm{mol} / \mathrm{m}^{2} / \mathrm{s}^{8)}$ との報告がある。これらの結果と比較し, 本研究で得られた 4 種の常緑広葉樹は, 光補償点からは熱帯林下 層に生育する而陰性を有する樹木の個葉之同程度の特性を, 暗呼 吸速度からは, 熱帯産の樹木よりも多少耐陰性の劣る特性である と考えられる。
このように屋外条件下に比べて遮光条件下では耐陰性が若干增 加し, 低光量アトリウム空間内での 3 年間の生育により, さらに 耐陰性が増加し，低光量条件下へ適応したと考えられた。

遮光または屋外条件下に生育するモチノキ,クロガネモチは, 高光量域において，陽樹であるアカメガシワと同程度の大きな光 合成特性を示す一方, 室内条件下では, 屋外条件下と比べて, 光 補償点, 暗呼吸速度の減少の変化が考えられ, 生育環境に応じて, 光合成特性の可塑性が大きな樹種であることが明らかとなった。

\section{謝辞}

なお，本研究を行うにあたり，関西国際空港株式会社の関係者 各位には多大なご協力をいただいた。また京都大学大学院森林水 文学研究室の小杉緑子助手には有益な助言をいただいた。ここに 心より謝意を表します。

\section{引用文献}

1) Bazzaz, F. B. and R. W. Carlson (1982): Photosynthetic acclimation to variability in the light environment of early and late successional plants : Oecologia 54, 313316

2) Bohning, R. H. and C. A. Burnside (1956): The effect of light intensity on rate of apparent photosynthesis in leaves of sun and shade plants : Am. J. Bot. 43, $557-561$

3 ) Collins, P. C. and T. M. Blessington (1983) : Postharvest effects of shipping temperatures and subsequent interior keeping quality of Ficus benjamina: HortScience 18(5), 757-758

4 ) Conover, C. A. and R. T. Poole (1975) : Acclimatization of tropical trees for interior use : HortScience 10(6), 600-601

5 ）遠藤明男・及川武久（1985）: 生育光 環境を異にするシラカシ幼樹の冬季の 光合成・蒸散特性: 日生態会誌 35 , 121-131

6) Fonteno, W. C. and E. L. McWilliams (1978) : Light Compensation Points and Acclimatization of Four Tropical Foliage Pl ants : J. Amer. Soc. Hort. Sci 103(1), 52-56
7) Hashimoto, Ryoji and T. Suzaki (1979): Studies on the response of photosynthesis to light intensity in leaves attached at various positions in trees crowns of a Cryptomeria japonica even-aged stands Effects of shading and leaf aging : J.Jap.For.Soc. 61(6), 193-201

8 ) Kitajima, Kaoru (1994): Relative importance of photosynthesis traits and allocation patterns as correlates of seedling shade tolerance of 13 tropical trees : Oecologia 98, 419-428

9 ) 清田信・西村正英 - 松下敦彦 - 大東秀 章・相賀一郎（1994）：二酸化炭素濃 度上昇が Acacia mangium 幼樹の ガス交換および生長におよぼす影響： 第 7 回環境情報科学論文集, 19-23

10）栗田端江・河村止・近藤三雄（1995）: 室内の低照度条件下における造園植物 の生育可能性について：造園雑誌 $59(1), 12-23$

11) Manaker, G. H. (1987): Interior Plantscapes(2nd edn.) : PrenticeHall, Inc, pp.324

12) Marler, T. M., B. Schaffer and J. H. Crane (1994): Developmental light level affects growth, morphology and leaf physiology of young Carambola trees : J. Amer. Soc. Hort. Sci, 119(4), 711-718
13）松本陽介・根岸賢一郎（1982）：林内 および伐採跡地に生育するシラべ前生 稚樹の光合成・呼吸：日林誌 64(5), $165-176$

14）中村彰宏・梶川剛史・奥村信一・中川 育男・森本幸裕（1996）：アトリウム 環境での植栽樹木の光合成特性：第 28 回日本緑化工学会研究発表会要旨 集, 118-119

15）日本建築学会編（1994）：アトリウム の環境設計：彰国社, $149 \mathrm{pp}$

16）日本造園学会編（1978）：造園ハンド ブック：技報堂出版, $1350 \mathrm{pp}$

17）沼田真（1977）: 群落の遷移とその機 構 植物生態学講座 4 : 朝倉書占, 306pp

18) Pearcy, R. W. and H. W. Calkin (1983): Carbon dioxide exchange of $\mathrm{C} 3$ and $\mathrm{C} 4$ tree species in the understory of a Hawaiian forest : Oecologia 58, 26-32

19）島田和則（1994）: 高尾山における先 駆性高木種 5 種の地形分布之樹形の意 義 : 日生態会誌 44, 293-304

20）島田緑了（1992）：光合成・蒸散過程 の統合的理解について( I )：日本緑 化工学会誌 17(4)，224-235

21）丹下健・鈴木誠・糟谷重夫・糟谷伊左 義（1991）: 被陰条件下で育てたスギ, 七ノキ苗木の被陰解除前後の光合成特 性と成長：日林誌 73(4)，288-292

Summary: Photosynthetic characteristics of 4 broad leaved woody species (Ternstroemia gymnanthera, Ilex rotunda, Ilex integra and Michelia figo) under different light environments (full sun, shaded and interior condition) were measured in an atrium building for detached leaves. These 4 species had lower dark respiration and light compensation points than that of Mallotus japonicus which is a sun tree and differs from $M$. japonicus in photosynthetic characteristics. Shade tolerances of 4 species increased under $70 \%$ shaded condition, those under interior condition increased furthermore. I. rotunda and I. integra under full sun or shaded condition had high photosynthetic rate like $M$. japonicus at relative high light level. On the other hand, these two species had lower dark respiration and light compensation points which are almost at the same rate of trees in understory of tropical rain forest. So these two species seem to have high photosynthetic plasticity. 